\title{
Neutrophil Attractant Protein-1-Immunoglobulin G Immune Complexes and Free Anti-NAP-1 Antibody in Normal Human Serum
}

\author{
llona Sylvester, * Teizo Yoshimura, * Michael Sticherling, ${ }^{*}$ Jens-M. Schröder, ${ }^{*}$ \\ Miroslav Ceska," Peter Peichl," and Edward J. Leonard* \\ *Immunopathology Section, Laboratory of Immunobiology, National Cancer Institute, Frederick Cancer Research and Development \\ Center, Frederick, Maryland 21702; ${ }^{\ddagger}$ Department of Dermatology, University of Kiel, 2300 Kiel, Federal Republic of Germany; ${ }^{\$}$ Sandoz \\ Forschungsinstitut, Vienna, Austria; and "Kaiser Franz Joseph Hospital, Department of Rheumatology, Vienna, Austria
}

\begin{abstract}
After obtaining data indicating the presence of a neutrophil attractant protein-1 (NAP-1)-IgG complex in normal human serum, we developed sandwich ELISAs that could quantify NAP-1 and NAP-1-IgG in mixtures of the two moieties. The ELISA for free NAP-1 used a monoclonal capture antibody that did not bind NAP-1-IgG. The ELISA for NAP-1-IgG was based on omission of the anti-NAP-1 detection antibody (required for the free NAP-1 ELISA) and on interaction of phosphatase-conjugated anti-human IgG with the human NAP-1IgG complex. Gel filtration of immunoaffinity-purified NAP1-IgG showed that the bulk of the complex comprised a single IgG. Binding between NAP-1 and antibody is strong, since $8 \mathrm{M}$ urea at neutral or alkaline pH did not release NAP-1. However, at pH 2.0 in $9 \mathrm{M}$ urea $\sim 15 \%$ of the total NAP-1 could be dissociated from the complex. NAP-1-IgG was detected in 18 of 26 sera from normal humans. The mean serum concentration was $58 \mathrm{ng}$ of IgG-bound NAP-1/ml, with an SEM of 16 and a range from undetectable to $247 \mathrm{ng} / \mathrm{ml}$. NAP-1-IgG concentrations in paired sera drawn at a 1-mo interval were remarkably constant. Using an ELISA for free NAP-1 with a detection limit of $200 \mathrm{pg} / \mathrm{ml}$, we found no free NAP-1 in the 26 sera. Free anti-NAP-1-IgG autoantibody was found in 9 of 26 sera by direct ELISA. IgG anti-NAP-1 of all nine sera was polyclonal, comprising both kappa and lambda isotypes; predominant subclasses were IgG2 and IgG3. NAP-1-IgG did not compete with ${ }^{125}$ I-NAP-1 for binding to neutrophils, which suggests that IgG anti-NAP-1 is a molecular trap that prevents binding of NAP-1 to neutrophils after it diffuses from production sites into the circulation. (J. Clin. Invest. 1992. 90:471-481.) Key words: interleukin-8 - chemoattractant • autoantibody • neutrophil • ELISA
\end{abstract}

\section{Introduction}

Human neutrophil attractant protein-1 (NAP-1) ${ }^{1}$ is a chemoattractant for neutrophils, but not monocytes. It is an $8,400-\mathrm{D}$

Address reprint requests to Dr. Edward J. Leonard, Building 560, Room 12-71, National Cancer Institute, FCRDC, Frederick, MD 21702.

Received for publication 8 August 1991 and in revised form $27 \mathrm{Feb}$ ruary 1992.

1. Abbreviations used in this paper: NAP-1, neutrophil attractant protein-1 (commonly called interleukin-8 [1]); TBS, Tris-buffered saline; TNF, tumor necrosis factor.

The Journal of Clinical Investigation, Inc.

Volume 90, August 1992, 471-481 protein, which was recently isolated, sequenced, and cloned (for review see reference 2). NAP-1 is synthesized and secreted by LPS-stimulated monocytes or macrophages. It is also secreted by numerous other cells, including epithelial and endothelial cells, lymphocytes, fibroblasts, and keratinocytes. The list of NAP-1 production stimuli, which includes LPS, zymosan, IL-1, TNF, and rubella, suggests that NAP-1 is a host defense cytokine, which is secreted as part of the response to noxious or infectious agents (2). This view is supported by the sequence similarity of NAP-1 to a family of small host defense proteins (3) and by detection of NAP-1 at inflammatory sites characterized by neutrophil infiltration. The latter include extraction of NAP-1 from human psoriatic scales (4), purification of NAP-1 from zymosan-induced rabbit peritoneal exudate (5), and detection of NAP-1 by immunoassay in synovial fluid of patients with arthritis (6) and in bronchoalveolar lavage fluid of cystic fibrosis patients infected with Pseudomonas (7).

Since NAP-1 is resistant to proteolytic digestion (8), the intact molecule may diffuse from its production source at sites of infection 'or tissue injury into the circulation. We therefore used a recently developed ELISA for NAP-1 (9) to determine if this chemoattractant was detectable in sera from healthy humans and patients with inflammatory joint effusions. Exploration of preliminary results led to the work reported here, which shows that serum of normal subjects contains a NAP-1-IgG complex and also free anti-NAP-1 antibody. The data suggest that under physiological conditions NAP-1 is released at tissue sites, where neutrophils can respond to the NAP-1 concentration gradient. NAP-1 subsequently diffuses into the blood where NAP-1 is prevented from binding to its target neutrophils by forming a complex with IgG anti-NAP-1.

\section{Methods}

Serum samples. Blood samples from 26 healthy volunteers were drawn into iced syringes, and cells were removed immediately by centrifugation at 3,000 rpm, $4^{\circ} \mathrm{C}$ (centrifuge model TJ-6; Beckman Instruments, Inc., Palo Alto, CA). Supernatants were transferred into glass tubes and incubated at $37^{\circ} \mathrm{C}$ for $\sim 30$ min to allow clotting. After the clot was removed, serum samples were filtered through $0.45-\mu \mathrm{m}$ pore-size Centrex filter units. Aliquots were stored at $-80^{\circ} \mathrm{C}$ until assay. Serum samples from 12 of the 26 donors were obtained twice, 1 mo apart, and paired sera were assayed for NAP-1-IgG and free NAP-1 on the same day.

Sandwich ELISAs for NAP-1. Mouse monoclonal TY anti-NAP-1 and rabbit polyclonal anti-NAP-1 IgG antibodies (9), monoclonal $8 \mathrm{C} 4,14 \mathrm{E} 4$, and 52E8 anti-NAP-1 antibodies (10), monoclonal 1C anti-NAP-1 $(11,12)$, and other reagents required for the ELISA (9) have been previously described. Mouse monoclonal anti-NAP-1 as a capture antibody was bound to 96 -well polystyrene microtiter plates (Beckman Instruments, Inc.) by incubation overnight at $4^{\circ} \mathrm{C}$ in coat- 
ing buffer ( $\mathrm{pH} 9.6$ ), at an IgG concentration of $9 \mu \mathrm{g} / \mathrm{ml}$. Unoccupied sites on the plastic were blocked by $0.2 \%$ BSA in coating buffer unless otherwise noted. After washing with $\mathrm{pH} 7.5$ Tris-buffered saline (TBS) $+0.05 \%$ Tween-20 (washing buffer), serial dilutions of samples and reference NAP-1 in washing buffer were added to the plates and incubated $90 \mathrm{~min}$ at $37^{\circ} \mathrm{C}$. Plates were then washed twice with washing buffer. Polyclonal rabbit anti-NAP-1 IgG at a concentration of $5 \mu \mathrm{g} / \mathrm{ml}$ in washing buffer containing $0.1 \%$ BSA was added to the wells to detect bound antigen. After two washing steps, anti-rabbit IgG alkaline phosphatase conjugate (Sigma Chemical Co., St. Louis, MO) diluted 1:1000 in washing buffer was added and incubated for $90 \mathrm{~min}$ at $37^{\circ} \mathrm{C}$. Plates were then washed six times with TBS without Tween-20 and developed with an ELISA amplification system (Bethesda Research Laboratories, Bethesda, MD), according to the instructions of the manufacturer. Absorbance at $490 \mathrm{~nm}$ was measured with an automated ELISA reader. (Absorbance was measured at $405 \mathrm{~nm}$ if the ELISA amplification system was not used). Concentration of NAP-1 in the samples was determined from the steep portion of the reference NAP-1 dose-response curve.

To test for the presence of human serum IgG that can bind to mouse IgG (heterophilic antibodies, [13]), ELISA wells were coated with normal mouse IgG (Sigma Chemical Co.) at a concentration of 10 $\mu \mathrm{g} / \mathrm{ml}(1 \mu \mathrm{g} /$ well $)$; after blocking with $0.2 \%$ BSA, human serum samples were incubated in the coated wells. The ELISA was developed with alkaline phosphatase-conjugated goat anti-human IgG.

Sandwich ELISA for NAP-1 with biotinylated rabbit IgG anti-NAP1. Biotinylation of polyclonal rabbit anti-NAP-1 IgG was performed after dialyzing $1 \mathrm{mg} \mathrm{IgG}$ against $0.1 \mathrm{M} \mathrm{NaHCO}_{3}$ overnight at $4^{\circ} \mathrm{C}$. NHS-biotin (Pierce Chemical Co., Rockford, IL) was dissolved in DMSO at a concentration of $1 \mathrm{mg} / \mathrm{ml}$ and $75 \mu \mathrm{l}$ of this solution was added to $1 \mathrm{ml}$ of $1 \mathrm{mg} / \mathrm{ml} \mathrm{IgG} \mathrm{in} 0.1 \mathrm{M} \mathrm{NaHCO}_{3}$. After equilibration on a shaker for $4 \mathrm{~h}$ at room temperature, the solution was dialyzed overnight against $0.05 \mathrm{M}$ TBS (pH 8.1) at $4^{\circ} \mathrm{C}$. Biotinylated $\mathrm{IgG}$ was then centrifuged at $10,000 \mathrm{rpm}$ for $15 \mathrm{~min}$ and $0.1 \% \mathrm{NaN}_{3}$ was added as a preservative. The preparation was kept at $4^{\circ} \mathrm{C}$.

The initial ELISA steps (coating with monoclonal capture antibody, blocking, addition of human serum for assay) were identical to those described above. Wells were then incubated with biotinylated rabbit anti-NAP-1, followed by two 15-min room temperature equilibrations. The first was with avidin (Vector Laboratories, Inc., Burlingame, CA) at a concentration of $10 \mu \mathrm{g} / \mathrm{ml}$ in $0.1 \mathrm{M} \mathrm{NaHCO}_{3}$; the second was with biotinylated alkaline phosphatase (Vector Laboratories, Inc.) at a concentration of $0.2 \mathrm{U} / \mathrm{ml}$ in TBS $+0.05 \%$ Tween-20). Finally, after six washes with TBS without Tween-20, the ELISA Amplification System was used to develop the reaction, and absorbance at $490 \mathrm{~nm}$ was recorded.

Direct ELISA. We examined specificity of monoclonal and rabbit polyclonal anti-NAP-1 antibodies by this method. Purified antigens (NAP-1, NAP-2, CTAP-III) were dissolved in coating buffer and bound to ELISA wells by overnight equilibration at $4^{\circ} \mathrm{C}$. Vacant sites were blocked with $0.2 \%$ BSA diluted in coating buffer. Rabbit or mouse anti-NAP- 1 in washing buffer at a concentration of $5 \mu \mathrm{g} / \mathrm{ml}$ was added and incubated for $90 \mathrm{~min}$ at $37^{\circ} \mathrm{C}$. Bound rabbit or mouse anti-NAP-1 was detected with alkaline phosphatase-conjugated antibody to mouse or rabbit IgG.

Purification of HSA for blocking ELISA plates. For purification of HSA (14), $100 \mathrm{ml}$ of serum was heated at $56^{\circ} \mathrm{C}$ for $30 \mathrm{~min}$. Ammonium sulfate was added slowly to continuously stirred serum at room temperature until the concentration was $2 \mathrm{M}$. After removal of precipitate by centrifugation, $\mathrm{pH}$ of the supernatant was adjusted to 4.0 with $0.3 \mathrm{~N} \mathrm{HCl}$. Precipitated protein was separated by centrifugation, suspended in potassium phosphate buffer $(0.1 \mathrm{M}, \mathrm{pH} 7.0)$, and dissolved by dialysis overnight against several changes of $0.15 \mathrm{M} \mathrm{NaCl}, 0.01 \mathrm{M}$ potassium phosphate $(\mathrm{pH} 7.0)$. The albumin solution was passed through a Protein-G Sepharose column five times to remove residual IgG. The purified HSA did not react with alkaline phosphatase-labeled goat anti-human IgG in a direct ELISA and was effective as a blocking protein to prevent binding of subsequent reagents to the ELISA wells.
ELISA for free anti-NAP-1 antibody in normal human sera. Human recombinant NAP- 1 at a concentration of $2 \mu \mathrm{g} / \mathrm{ml}(200 \mathrm{ng} /$ well $)$ in coating buffer was added to ELISA wells and equilibrated overnight at $4^{\circ} \mathrm{C}$. Unoccupied sites on the plastic were blocked by $0.3 \mathrm{ml} /$ well of purified HSA (purified as described above) diluted in coating buffer to a concentration of $1 \mathrm{mg} / \mathrm{ml}$. Control wells to which NAP-1 had not been added were also blocked with HSA. Blocking with IgG-free HSA resulted in a lower background than with BSA and was critical for detection and quantitative estimation of anti-NAP-1. After one wash, serum samples at $1: 2$ dilution in washing buffer were added to triplicate wells and incubated $2 \mathrm{~h}$ at $37^{\circ} \mathrm{C}$. Bound $\mathrm{IgG}$ was detected by alkaline phosphatase-conjugated goat anti-human IgG (Jackson ImmunoResearch Labs, Inc., West Grove, PA). The reaction was developed with $p$-nitrophenyl phosphate disodium (Sigma 104 Phosphatase Substrate Tablet; Sigma Chemical Co.), and absorbance was measured at $405 \mathrm{~nm}$ with an automated ELISA reader. For each serum sample, the difference between NAP-1 well and control well $\mathrm{A}_{405}$ was attributable to free anti-NAP-1. Control reactions of anti-human IgG with HSA and antihuman IgG with NAP-1 were negative.

After identifying serum samples with detectable free anti-NAP-1 antibody, we repeated the assay to make quantitative estimates of antibody concentration by relating serum ELISA $\mathrm{A}_{405}$ values to a simultaneously obtained anti-NAP-1 dose-response standard curve generated by interaction of dilutions of monoclonal anti-NAP-1 with $200 \mathrm{ng} /$ well of recombinant NAP-1. Background $\mathrm{A}_{405}$ was subtracted from standard curve ELISA values. Background $\mathrm{A}_{405}$ for the standard curve was obtained by sequential addition of HSA, monoclonal anti-NAP-1, and anti-mouse IgG-AP-conjugate. Serum samples were assayed at 1:3 dilution in triplicate wells coated with NAP-1. Serum background values were obtained by addition of serum to HSA-blocked wells without the NAP-1 coating. The difference in $\mathrm{A}_{405}$ between serum added to NAP1-HSA wells and HSA background wells was due to free anti-NAP-1. An estimate of anti-NAP-1 concentration was determined graphically by reference to the monoclonal anti-NAP-1 standard curve.

Additional assays were performed to determine the IgG subclass and the light chain isotype of IgG anti-NAP-1 autoantibody in sera of normal human subjects. Serum IgG from these subjects was purified on Protein-G columns and adjusted to a concentration of $1 \mathrm{mg} / \mathrm{ml}$. ELISA plates, except for control wells, were coated with NAP-1 and blocked with HSA as in the above procedure. We then added $1 \mathrm{mg} / \mathrm{ml}$ purified IgG from the series of human subjects or $1 \mathrm{mg} / \mathrm{ml}$ normal human IgG (ChromoPure; Jackson ImmunoResearch Labs., Inc.) to triplicate wells. Light chain isotype was probed by addition of mouse monoclonal anti-human kappa- and lambda-light chain antibodies (Boehringer Mannheim GmbH, Mannheim, FRG), followed by alkaline phosphatase-labeled goat anti-mouse IgG (Sigma Chemical Co.). IgG subclasses were determined with subclass-specific mouse mAbs (HP6069 anti-IgG1, HP6002 anti-IgG2, HP6047 anti-IgG3, and HP6023 anti-IgG4) produced by Hybridoma Reagent Laboratory (Kingsville, MD). Absorbance values due to HSA-IgG interaction were subtracted from those of the NAP-1-containing wells. No crossreactivity between bound human IgG and alkaline phosphatase-conjugated anti-mouse IgG was detected.

LPS stimulation of human blood mononuclear leukocytes. Donors S.I. and E.L. (one with undetectable and the other with high serum NAP-1-IgG) were selected to determine if there was a quantitative difference between NAP-1 production by their LPS-stimulated PBMCs. $50 \mathrm{ml}$ of blood from each donor was drawn into sterile syringes containing $500 \mathrm{U}$ heparin sodium ( The Upjohn Company, Kalamazoo, MI). After Ficoll-Hypaque separation and three washing steps, cells were resuspended in RPMI 1640 (Advanced Biotechnologies, Inc., Silver Spring, MD) containing 5\% heat-inactivated FCS (Hyclone Laboratories Inc., Logan, UT), $2 \mathrm{mM}$ L-glutamine, $50 \mu \mathrm{g} / \mathrm{ml}$ gentamycin sulfate, and $10 \mu \mathrm{g} / \mathrm{ml}$ Escherichia coli LPS 055:B5 (Difco, Detroit, MI). Cells were incubated at a concentration of $5 \times 10^{6} \mathrm{cells} / \mathrm{ml}$ in a Costar 24-well tissue culture plate (Costar Corp., Cambridge, MA) for $36 \mathrm{~h}$ at $37^{\circ} \mathrm{C}$. Cell-free supernatants were obtained by centrifugation and filtration through $0.45-\mu \mathrm{m}$ pore-size Centrex filter units. Cells 
for the control were incubated without LPS; after incubation, LPS was added to the cell-free supernatants at a concentration of $10 \mu \mathrm{g} / \mathrm{ml}$. NAP-1 concentration was determined by sandwich ELISA.

Affinity chromatography of human serum on a monoclonal antiNAP-1 column. $12 \mathrm{mg}$ of purified monoclonal anti-NAP-1 IgG was coupled to $3.5 \mathrm{ml}$ packed volume of $\mathrm{CNBr}$-activated Sepharose 4B (Pharmacia-LKB, Piscataway, NJ). After a preliminary wash of the column with $0.1 \mathrm{M}$ glycine- $\mathrm{HCl}$ buffer ( $\mathrm{pH} 2.5$ ) and equilibration with PBS, $25 \mathrm{ml}$ or $8.5 \mathrm{ml}$ of filtered human serum was passed through the column at a flow rate of $0.5 \mathrm{ml} / \mathrm{min}$. After the column was washed with $50 \mathrm{ml} 2 \mathrm{M} \mathrm{NaCl}$, bound proteins were eluted with $0.1 \mathrm{M}$ glycine- $\mathrm{HCl}$ buffer ( $\mathrm{pH} 2.5$ ). 1-ml fractions were collected into Minisorp tubes (Nunc, Copenhagen, Denmark) containing $0.1 \mathrm{ml}$ of $0.5 \mathrm{M}$ potassium phosphate buffer ( $\mathrm{pH} 7.8$ ). Absorbance was measured at $280 \mathrm{~nm}$. A pool of $A_{280}$ positive fractions was dialyzed overnight at $4^{\circ} \mathrm{C}$ against TBS or PBS, depending on requirements of the subsequent assay. A column of mouse monoclonal IgG directed against a protein unrelated to NAP-1 and an uncoupled CNBr-Sepharose 4B column (blocked with $0.1 \mathrm{M}$ Tris- $\mathrm{HCl}$ buffer, $\mathrm{pH} \mathrm{8.0)}$ ) of the same size were used for controls.

HPLC gel filtration of anti-NAP-1 column eluate and untreated human serum. HPLC gel filtration of $100-\mu l$ samples was performed at room temperature on a $7.5 \times 600 \mathrm{~mm}$ TSK- 2000 column (Toyo Soda, Tokyo, Japan), equilibrated with Dulbecco's PBS ( $\mathrm{pH}$ 7.4). 1-ml fractions were collected at a flow rate of $1 \mathrm{ml} / \mathrm{min}$, and $A_{280}$ was recorded at an absorbance range of 0.16 . The column was calibrated with catalase, ribonuclease (both from Pharmacia-LKB), and ChromoPure human IgG. Fractions were assayed in the sandwich ELISA with both biotinylated rabbit anti-NAP-1 and enzyme-linked anti-human IgG as detecting antibodies.

$S D S-P A G E$ of anti-NAP-1 column eluate. Electrophoresis was carried out on a vertical slab gel of $7.5 \%$ acrylamide with a Tris-glycine buffer system. Anti-NAP-1 column eluate and control mouse IgG were mixed with equal volumes of double-strength sample buffer ( $20 \%$ glycerol, $4 \%$ SDS, without 2-mercaptoethanol), boiled, and applied to the gel in amounts of 5,10 , and $20 \mu \mathrm{g} /$ lane. After a $2-\mathrm{h}$ run at $16 \mathrm{~mA}$, the gel was removed and stained with Coomassie blue.

Gel filtration in 8 or $9 M$ urea at different $p H s$. Anti-NAP-1 column eluate from human serum was concentrated on a Centricon-10 to a final concentration of $10 \mathrm{mg} / \mathrm{ml}$ protein. Aliquots were dialyzed against the following running buffers: buffer a: TBS, pH $7.4(0.1 \mathrm{M}$ Tris, $0.15 \mathrm{M} \mathrm{NaCl}$ ); buffer b: glycine-HCl buffer, $0.1 \mathrm{M}, \mathrm{pH} \mathrm{2.0; \text {and }}$ buffer c: carbonate buffer, $0.05 \mathrm{M}, \mathrm{pH} 10.0$ ). Urea was added to each sample to make a concentration of $8 \mathrm{M}$ in buffers a and c, or $9 \mathrm{M}$ in buffer b. $2 \mathrm{ml}$ of sample was applied to a $250 \mathrm{~mm}$ long Sephadex G-100 column equilibrated with buffer $\mathrm{a}, \mathrm{b}$, or $\mathrm{c}$, containing 8 or $9 \mathrm{M}$ urea. $2-\mathrm{ml}$ fractions were collected at a flow rate of $6 \mathrm{ml} / \mathrm{h}$. The column was calibrated with ChromoPure human IgG, ChromoPure HSA (both from Jackson ImmunoResearch Labs, Inc.), chymotrypsinogen (Pharmacia LKB), and cytochrome $c$ (Sigma Chemical Co.). Fractions were dialyzed overnight against several changes of TBS at $4^{\circ} \mathrm{C}$ and then were assayed by sandwich ELISA with biotinylated and nonbiotinylated rabbit antibodies. The sandwich ELISA with nonbiotinylated rabbit antibody was performed with two mouse monoclonal anti-NAP-1 capture antibodies, TY and IC, which are directed against different epitopes of NAP-1.

Iodination of NAP-1. NAP-1 was iodinated with Bolton-Hunter reagent ( $N$-succinimidyl-3-(4-hydroxy-3-[ $\left.{ }^{125} \mathrm{I}\right]$ iodophenyl)propionate) purchased from New England Nuclear Research Products (Boston, MA). After the benzene solvent was evaporated, $10 \mu \mathrm{g}$ of recombinant NAP- 1 in $10 \mu$ of $0.1 \mathrm{M}$ sodium borate buffer, $\mathrm{pH} 8.5$, was added to the dried iodinated ester at $0^{\circ} \mathrm{C}$. After $1 \mathrm{~h}, 50 \mu \mathrm{g} / \mathrm{ml}$ of cytochrome $c$ in borate buffer was added to make a final volume of $160 \mu$ l. The solution was added to a 320- $\mu$ l column of Sephadex G-25, which had a void volume of $160 \mu$. The protein peak was then eluted by addition of 110 $\mu \mathrm{l}$ of cytochrome $c$ solution. Recovery of iodinated NAP-1 was assumed to be $46 \%$, based on recovery of a similar volume of albumin solution on a companion column.
Inhibition of iodinated NAP-1 binding to neutrophils by NAP-1 or NAP-1-IgG. Human venous blood neutrophils were purified by dextran sedimentation and suspended at a final concentration of $10^{7} / \mathrm{ml}$ in HBSS without calcium or magnesium, containing $100 \mu \mathrm{g} / \mathrm{ml}$ of low endotoxin bovine albumin (Fraction V; Miles Laboratories Inc., Research Products Div., Elkhart, IN). To a series of equilibration tubes we added $50 \mu \mathrm{l}$ of ${ }^{125} \mathrm{I}$-NAP-1 $\left(1.2 \times 10^{-8} \mathrm{M}\right), 50 \mu \mathrm{l}$ of diluent or a series of increasing concentrations of NAP-1 or NAP-1-IgG, and then $100 \mu \mathrm{l}$ of neutrophil suspension. After $2 \mathrm{~h}$ in a melting ice bath, the contents of each tube were transferred to microfuge tubes (catalogue no. 314326; Beckman Instruments Inc.) containing $0.1 \mathrm{ml}$ of an 1:1.5 mixture of dioctyl and dibutyl phthalate. The tubes were centrifuged for $0.5 \mathrm{~min}$ in an Eppendorf centrifuge. The tips of the tubes containing the cell pellets were cut off and transferred to a gamma counter.

\section{Results}

Reactivity of normal serum in the NAP-1 sandwich ELISA. Sylvester et al. (9) described a sandwich ELISA for NAP-1 with mouse monoclonal anti-NAP-1 as capture antibody, rabbit polyclonal anti-NAP-1 as detection antibody, and phosphatase-conjugated anti-rabbit IgG as the enzyme-linked reagent (Fig. $1 A$ ). When we used this ELISA to survey normal human serum for NAP-1, many sera had reactivity. However, in contrast to the sandwich ELISA for pure NAP-1, the serum reactivity did not require addition of the detection antibody (rabbit IgG anti-NAP-1). This is shown in Table I. Omission of the detection antibody (Step 3) abolished NAP-1 ELISA reactivity but had no effect on the serum ELISA reaction. This result suggested that the serum reactivity was not due to free NAP-1 but to a NAP-1-IgG complex that became bound to the capture antibody. The idea is outlined schematically in Fig. $1 B$, which indicates that ELISA color developed because phosphatase-conjugated anti-rabbit IgG cross-reacted with human IgG in the complex. Comparable serum ELISA values were obtained with phosphatase-conjugated anti-human IgG, which was used in subsequent assays to detect NAP-1-IgG (Table I).

Additional evidence relating to the NAP-1-IgG complex hypothesis. The absence of a requirement for anti-NAP-1 detection antibody shown in Table I could be explained by the presence in serum of a heterophilic antibody (not a NAP-1-IgG complex) that interacted with the mouse monoclonal IgG adsorbed to the ELISA well (13), without any relationship to the antigen specificity of the mAb. This possibility was tested by performing the serum sandwich ELISA in wells coated with normal mouse serum IgG or with mouse monoclonal IgGl antibodies directed against antigens unrelated to NAP-1 (see Methods). Cross-reactivity with mouse IgG was detected in all normal sera tested and varied with individual donors. However, this accounted for only a fraction of the absorbance obtained with specific anti-NAP-1 antibody. Values for net reactivity, attributable to NAP-1-IgG, are presented later in Results on NAP-1 ELISA of 26 normal sera.

Additional evidence for a serum IgG complex that interacted specifically with anti-NAP-1 was obtained by adding serum to a monoclonal anti-NAP-1 Sepharose column or a control column. After washing the columns, bound protein was eluted with pH 2.5 glycine buffer and assayed in the NAP-1 sandwich ELISA with phosphatase-labeled anti-human IgG [Table I, Step 3 eliminated]. As shown in Table II, ELISA reactivity was found in eluates from the anti-NAP-1 column, but not the control columns.

Mouse monoclonal TY anti-NAP-1, which was used as 


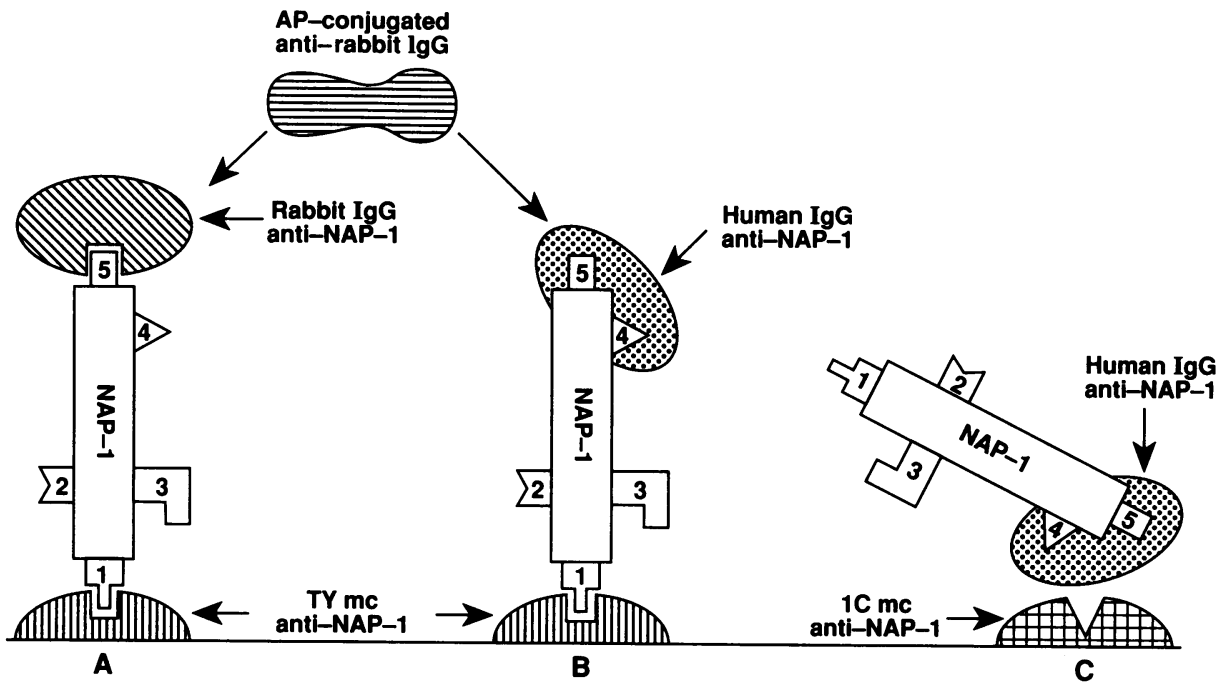
tase-conjugated anti-rabbit IgG, which cross-reacts with human IgG. $(C)$ Monoclonal $1 C$ anti-NAP-1, which reacts with NAP-1 epitope 4, can function as capture antibody for free NAP-1 (Table III). It cannot capture NAP-1-IgG, since epitope 4 is blocked. Therefore it can be used in a sandwich ELISA for quantifying free NAP-1 in mixtures of NAP-1 and NAP-1-IgG. Five distinct epitopes are postulated, based on the following antibody reactivities. Epitope 1: distinct from epitopes $2-4$, since antibody to epitope 1 cross-reacts with NAP-2 and CTAP-III, whereas antibodies to epitopes 2-4 do not. Epitope 2: reacts with antibodies 8C4 and 14E4; distinct from epitope 3, which reacts with antibody 52E8, since the latter can function as capture antibody in a sandwich ELISA with 8C4 or 14E4 as detection antibodies. Epitope 4: in free NAP-1, it reacts with monoclonal $1 \mathrm{C}$ anti-NAP-1 as capture antibody; but unlike epitopes 1-3, epitope 4 in NAP-1-IgG cannot react with monoclonal 1C (Fig. $1 C$ ). Epitope 5: in free NAP-1, it reacts with rabbit anti-NAP-1. Like epitope 4, epitope 5 in NAP-1-IgG cannot react with its corresponding antibody. It is likely that epitopes 4 and 5 are distinct (or are identical with duplicate copies in NAP-1), since a NAP-1 sandwich ELISA can be set up with epitope 4 and 5 capture and detection antibodies (Table III).

capture antibody, also bound human CTAP-III, a structurally related cytokine that is released from platelets (15). (Despite this cross-reactivity the sandwich ELISA did not detect CTAPIII, since our rabbit anti-NAP-1 detecting antibody did not bind to CTAP-III.) Therefore, it was important to determine whether the cytokine in the IgG complex bound by mouse monoclonal TY was NAP-1 or CTAP-III. Accordingly, we

Table I. NAP-1 Sandwich ELISA Showing Serum NAP-1 ELISA Reactivity Without Addition of Rabbit anti-NAP-1

Detection Antibody

\begin{tabular}{lllllll} 
& & \multicolumn{4}{c}{ TY monoclonal anti- } \\
Step 1 & Coating Ab* & \multicolumn{4}{c}{ NAP-1 } \\
Step 2 & Antigen $^{\ddagger}$ & \multicolumn{2}{c}{ NAP-1 } & \multicolumn{2}{c}{ Serum } \\
Step 3 & Rabbit IgG aNAP-1 $^{\S}$ & + & - & + & - \\
Step 4 & Anti-rabbit IgG" $^{\prime \prime}$ & + & + & + & + \\
$\quad$ ELISA A 490 & & 1.64 & 0.11 & 1.02 & 1.16 \\
Alternative Step 4 & & & & & \\
$\quad$ Anti-rabbit IgG" & & + & + & - & - \\
Anti-human IgG" & & - & - & + & + \\
ELISA A A90 $^{\prime \prime}$ & & 1.79 & 0.18 & 1.52 & 1.73
\end{tabular}

* Coating antibody: $0.1 \mathrm{mg} /$ well of $10 \mu \mathrm{g} / \mathrm{ml} \mathrm{TY}$ monoclonal $\mathrm{IgG}$ anti-NAP-1. ${ }^{\ddagger}$ Antigen concentrations: NAP-1, $25 \mathrm{ng} / \mathrm{ml}$; serum (E.L.), 1:10 dilution; ${ }^{8}$ Rabbit IgG anti-NAP-1: $5 \mu \mathrm{g} / \mathrm{ml}$. " Alkaline phosphatase-conjugated antibodies, developed in goat. 'After identifying NAP-1 ELISA reactivity in the serum as a complex of NAP-1 with human IgG, we used anti-human IgG in subsequent assays to detect NAP-1-IgG. Detection of free NAP-1 required addition of rabbit anti-NAP-1 antibody, followed by phosphatase-labeled antirabbit IgG. tested several mouse monoclonal IgG anti-NAP-1 antibodies in a direct ELISA for cross-reactivity with CTAP-III (see Methods). In contrast to mc TY anti-NAP-1, two other monoclonal anti-NAP-1 antibodies (8C4 and 14E4) did not cross-react with CTAP-III or NAP-2 (CTAP-III with the first 15 residues of the $\mathrm{NH}_{2}$ terminus deleted ). When these were used as capture antibodies in the sandwich ELISA, they detected both free

Table II. Specific Binding of NAP-1-IgG by Monoclonal Anti-NAP-1-Sepharose

\begin{tabular}{lc}
\hline & NAP-1-IgG eluted \\
\hline & $\mu g$ \\
Experiment I & \\
25 ml serum added to: & \\
Anti-NAP-1 Sepharose* & $2.5^{\ddagger}$ \\
$\quad$ Mouse IgG Sepharose & 0.04 \\
Experiment II & \\
8.5 ml serum added to: & \\
Anti-NAP-1 Sepharose & 5.8 \\
Control Sepharose & 0.05 \\
\end{tabular}

* The column contained $3.5 \mathrm{ml} \mathrm{CNBr-activated} \mathrm{Sepharose} \mathrm{4B} \mathrm{cou-}$ pled with $12 \mathrm{mg}$ of IgG TY monoclonal anti-NAP-1. The mouse IgG Sepharose column was coupled with $12 \mathrm{mg}$ of IgG antibody directed against an unrelated protein. The control Sepharose column for Experiment II was treated with $0.1 \mathrm{M}$ Tris- $\mathrm{HCl}$ at $\mathrm{pH} 8.0$ to inactivate combining groups. ${ }^{\ddagger}$ Nanograms of complex NAP-1 (not including weight of IgG) as determined by reference to a simultaneously determined standard curve for free NAP-1. 
Table III. Sandwich ELISA of NAP-1 and NAP-1-IgG with Different Monoclonal Capture Antibodies

\begin{tabular}{lcccc}
\hline & \multicolumn{4}{c}{ Antigen $^{*}$} \\
\cline { 2 - 5 } & NAP-1 & NAP-1-IgG & CTAP-III & TBS \\
\hline TY monoclonal aNAP-1 ${ }^{\ddagger}$ [1] & 1.46 & 1.88 & 0.12 & 0.12 \\
8C4 monoclonal aNAP-1 [2] & 1.21 & 1.40 & 0.18 & 0.22 \\
14E4 monoclonal aNAP-1 [2] & 1.34 & 1.63 & 0.25 & 0.27 \\
52E8 monoclonal aNAP-1 [3] & 1.10 & 1.02 & 0.10 & 0.08 \\
1C monoclonal aNAP-1 [4] & 2.22 & 0.18 & 0.10 & 0.08
\end{tabular}

* Antigen concentration: NAP-1, $25 \mathrm{ng} / \mathrm{ml}$; NAP-1-IgG, $50 \mathrm{ng}$ complex NAP-1/ml; CTAP-III, $65 \mathrm{ng} / \mathrm{ml}$. ${ }^{\ddagger}$ Capture antibody: $0.1 \mathrm{ml} /$ well of $9 \mu \mathrm{g} / \mathrm{ml} \mathrm{IgG}$ for all antibodies except $1 \mathrm{C} \mathrm{mc}$ aNAP-1 $(5 \mu \mathrm{g} / \mathrm{ml})$. Numbers in brackets refer to epitope with which capture antibody reacts, as shown in Fig. 1. Detection antibody was rabbit IgG antiNAP- $1,5 \mu \mathrm{g} / \mathrm{ml}$. The ELISA was developed with alkaline phosphatase-conjugated goat anti-rabbit IgG, followed by the ELISA amplification system. Values in the Table are $\mathrm{A}_{490}$.

NAP-1 and NAP-1-IgG (Table III). Since these anti-NAP-1 antibodies did not react with CTAP-III, we conclude that they captured the IgG complex via NAP-1 in the complex.

Assays to distinguish NAP-1 and NAP-1-IgG in mixtures. Monoclonal 1C anti-NAP-1 is unique among the antibodies listed in Table III: it was the best capture antibody for free NAP-1 but did not function as capture antibody for NAP-1IgG. Thus, it appears to interact with a NAP-1 epitope that is blocked in NAP-1-IgG, as indicated in Figure $1 C$. By using 1C monoclonal anti-NAP-1 as capture antibody in a sandwich ELISA, we could quantify free NAP-1 in mixtures of NAP-1 and NAP-1-IgG. As shown in Fig. 2, assay values for free NAP-1

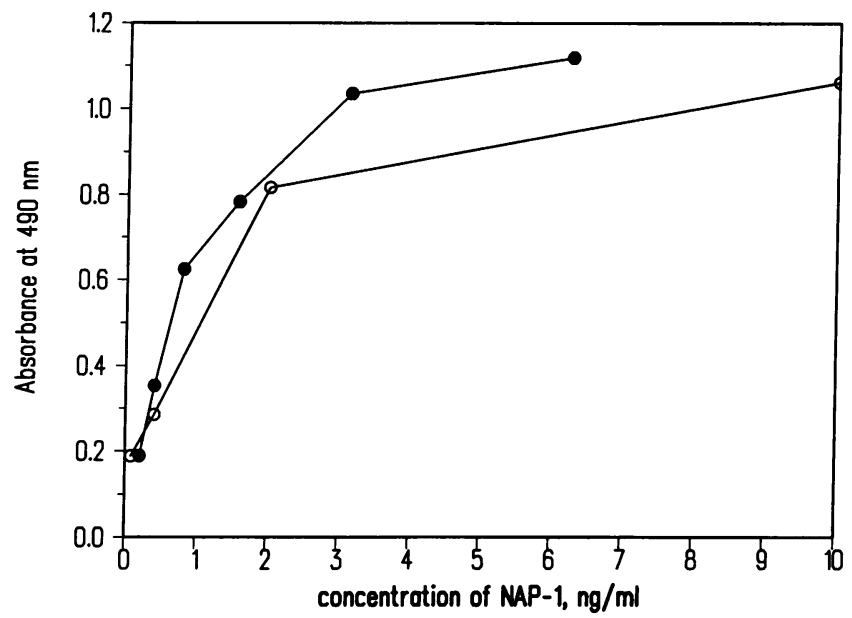

Figure 2. A sandwich ELISA that detects only free NAP-1 in mixtures of NAP-1 and NAP-1-IgG, based on using a monoclonal capture antibody that does not bind NAP-1-IgG. Capture antibody: 1C monoclonal anti-NAP-1, which is the only monoclonal antibody listed in Table III that did not react with NAP-1-IgG in a direct ELISA. Detection antibody: rabbit IgG anti-NAP-1. (Closed circles) Pure NAP-1, serially diluted in TBS. (Open circles) Serial fivefold dilutions of a solution of $10 \mathrm{ng} / \mathrm{ml}$ pure NAP-1 and $20 \mathrm{ng} / \mathrm{ml}$ NAP1-IgG. The presence of NAP-1-IgG at a concentration of $20 \mathrm{ng} / \mathrm{ml}$ in the solution of $10 \mathrm{ng} / \mathrm{ml}$ NAP-1 did not increase the ELISA absorbance values.

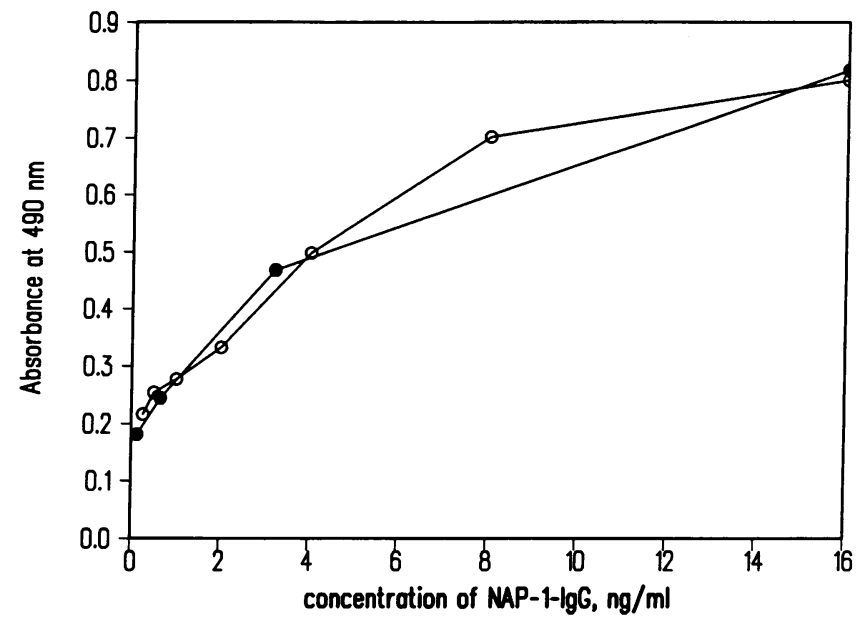

Figure 3. A sandwich ELISA that detects only NAP-1-IgG in a mixture of NAP-1-IgG and NAP-1, based on omission of rabbit IgG anti-NAP-1 detection antibody (Table 1, Step 3). Capture antibody: $0.1 \mathrm{ml} /$ well of TY monoclonal anti-NAP-1 at a concentration of 9 $\mu \mathrm{g} / \mathrm{ml}$. (Closed circles) Dilutions in TBS of a solution containing 16 $\mathrm{ng} / \mathrm{ml}$ of NAP-1-IgG and $15 \mathrm{ng} / \mathrm{ml}$ free NAP-1. (Open circles) Dilutions of $16 \mathrm{ng} / \mathrm{ml}$ NAP-1-IgG. The presence of free NAP-1 in the NAP-1-IgG solution did not increase ELISA values, since there was no anti-NAP-1 detection antibody in the assay.

were not increased by the presence of NAP-1-IgG. The converse is illustrated in Fig. 3, which shows that by omission of rabbit anti-NAP-1 detection antibody, NAP-1-IgG can be quantified in the presence of free NAP-1.

Since rabbit anti-NAP-1 played no role in the detection of NAP-1-IgG (Table I), it was possible that the free NAP-1 epitope (or epitopes) with which rabbit anti-NAP-1 reacted was blocked in the IgG complex. We confirmed this by a NAP-1 sandwich ELISA that used biotinylated rabbit anti-NAP-1 as

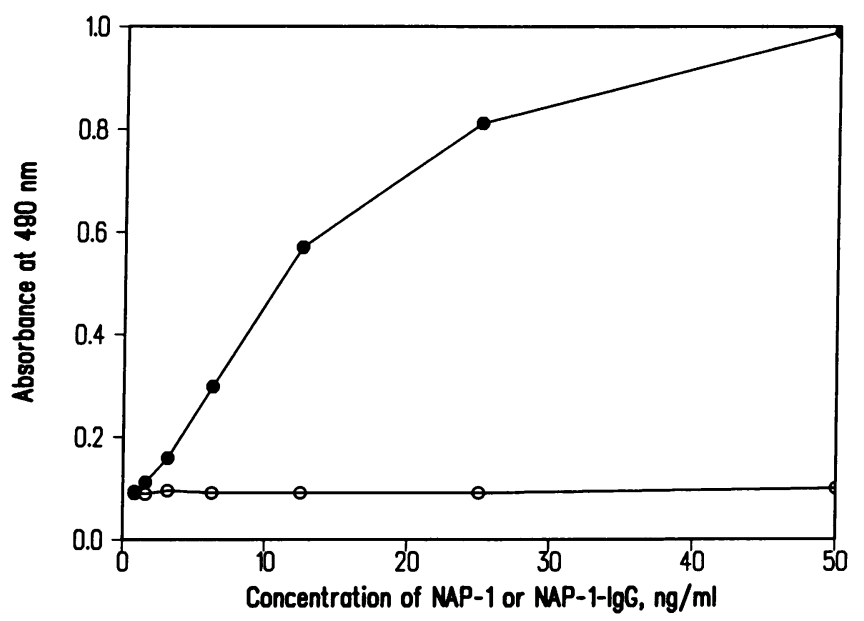

Figure 4. A sandwich ELISA that detects free NAP-1, but not NAP1-IgG, based on use of rabbit biotinylated IgG anti-NAP-1 as detection antibody. (Closed circles) Serial dilutions of NAP-1 in TBS. (Open circles) Dilutions of NAP-1-IgG in TBS. The concentration of NAP-1-IgG refers to weight of NAP-1, without the contribution of IgG. This assay did not detect NAP-1-IgG since enzyme conjugated anti-IgG (Table I, Step 4) was not required for generation of ELISA color. 




Figure 5. HPLC-TSK-2000 gel filtration of NAP-1-IgG. Human serum NAP-1-IgG was partially purified by elution from a monoclonal anti-NAP-1 Sepharose column. The concentrated eluate was applied to a TSK-2000 column. The $A_{280}$ of the effluent was continuously monitored. Fractions were assayed undiluted, 1:3 and 1:9 by sandwich ELISA for NAP-1-IgG; the graph ( $0-0)$ shows results for 1:3 dilutions of the fractions. Molecular mass markers: $A$, catalase; $B$, human IgG; C, ribonuclease. Inset: SDS-PAGE (nonreducing conditions) of NAP-1-IgG, showing that the bulk of the protein in this fraction is IgG. Molecular mass markers $(k D)$ : human IgG, BSA, ovalbumin, bovine carbonic anhydrase, hen egg white lysozyme.

the detecting antibody and thus avoided the use of an enzymeconjugated anti-rabbit IgG. When NAP-1-IgG was tested in this assay, no NAP-1 reactivity was found, indicating that biotinylated rabbit anti-NAP-1 did not bind to the NAP-1-IgG complex (Fig. 4). The legend of Fig. 1 summarizes our view of the number of NAP-1 epitopes and indicates the two that are blocked in NAP-1-IgG.

Characterization of NAP-1-IgG. To obtain concentrated NAP-1-IgG for characterization, we applied $25 \mathrm{ml}$ of fresh normal human serum containing $247 \mathrm{ng} / \mathrm{ml}$ of NAP-1-IgG to a monoclonal IgG anti-NAP-1 Sepharose column. Bound NAP-1-IgG was eluted and applied to a TSK-2000 HPLC column as described in Methods. The concentration of NAP-1-
IgG in fractions eluted from the TSK-2000 column was determined by sandwich ELISA. Fig. 5 shows that the bulk of the NAP-1-IgG coeluted with the major $A_{280}$ peak, which is in the location of the IgG marker. Therefore, the NAP-1-IgG complex comprises only one IgG plus one NAP-1 molecule (or at most two NAP-1s per divalent IgG). SDS-PAGE of the starting material applied to the TSK-2000 column showed that almost all the protein is IgG (Fig. 5, inset). However, NAP-1-IgG comprises only a small percentage of the total $\mathrm{IgG}$, which is evident from the $y$-axis scales in Fig. $5\left(A_{280}\right.$ values reflect $\mu \mathrm{gs}$ $\mathrm{IgG} / \mathrm{ml}$, in contrast to $\mathrm{ng} / \mathrm{ml}$ of complex ). This is due to nonspecific binding of serum IgG to Sepharose columns (including Sepharose alone, Sepharose coupled to mouse IgG, or Sepharose-IgG-anti-NAP-1), which is then eluted by $\mathrm{pH} 2.7$ glycine buffer.

We attempted to dissociate the NAP-1-IgG complex by gel filtration on Sephadex G-100 in 8 or $9 \mathrm{M}$ urea at $\mathrm{pH} 7.4,2.0$, and 10.0. Fig. 6 shows that at neutral $\mathrm{pH}$ we failed to dissociate the complex, since NAP-1 ELISA reactivity was eluted at the IgG marker and not in the location for free NAP-1. However, we altered the complex sufficiently to expose the two blocked epitopes outlined in Fig. $1 C$. In contrast to the undenatured complex, urea-treated NAP-1-IgG reacted in a sandwich ELISA that uses biotinylated rabbit anti-NAP-1 as detecting antibody; and it was captured by monoclonal 1C (Fig. 6, closed circles), which is incapable of binding the native NAP-1-IgG complex (Table III, last row; Fig. $1 C$ ). Although similar results were obtained at $\mathrm{pH} 10.0, \sim 15 \%$ of NAP- 1 in the NAP$1-\mathrm{IgG}$ complex was completely released in $9 \mathrm{M}$ urea at $\mathrm{pH} 2.0$ (Fig. 7).

Inhibition of iodinated NAP-1 binding to neutrophils by NAP-1, but not NAP-1-IgG. Human neutrophils have saturable binding sites for NAP-1 $(16,17)$. To explore the possibility that formation of NAP-1-IgG was a means of preventing interaction of NAP-1 with circulating neutrophils, we tested the capacity of NAP-1-IgG to interact with neutrophil NAP-1 receptors. This was done by comparing inhibition of ${ }^{125} \mathrm{I}-\mathrm{NAP}-1$ binding to neutrophils by free NAP-1 and NAP-1-IgG. Fig. 8 shows that, in contrast to NAP-1, increasing concentrations of

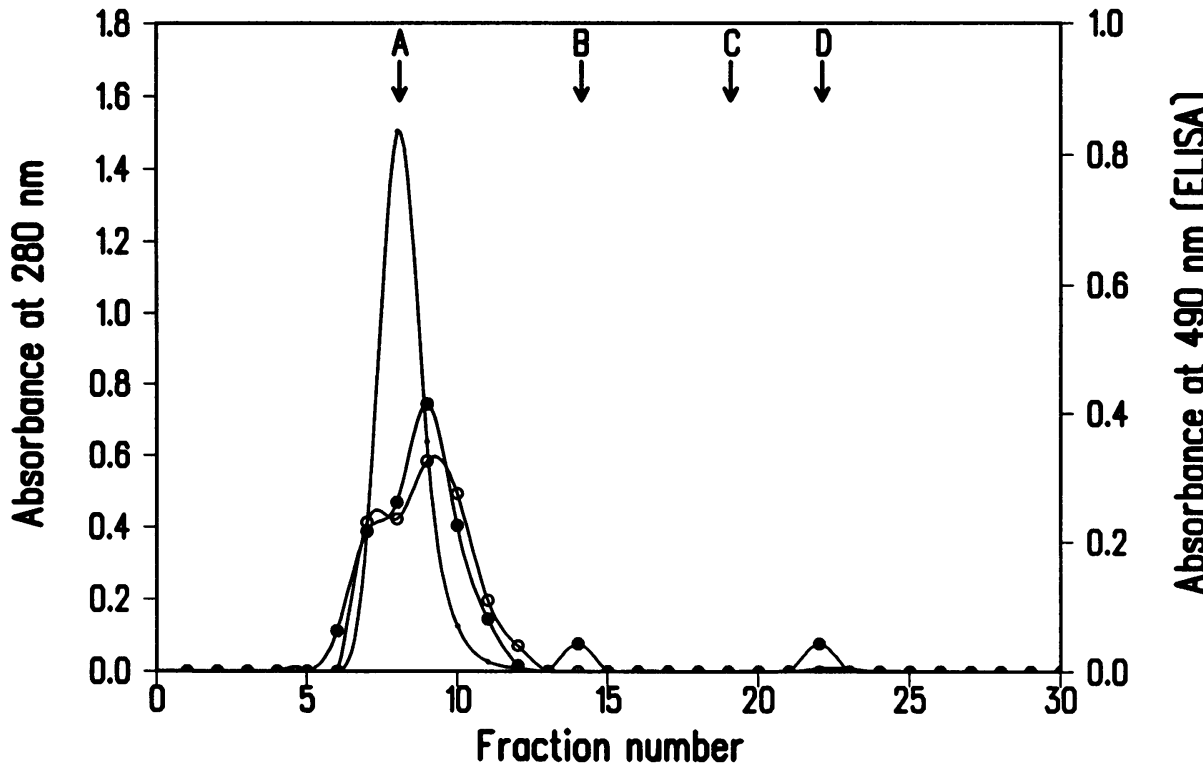

Figure 6. Gel filtration of NAP-1-IgG on Sephadex G-100 in $8 \mathrm{M}$ urea at $\mathrm{pH}$ 7.4. Serum NAP-1-IgG was partially purified and concentrated as noted for Fig. 4. Urea was added to a concentration of $8 \mathrm{M}$, and the sample was applied to a column of Sephadex G-100 equilibrated with $8 \mathrm{M}$ urea in TBS and eluted with the same buffer containing $8 \mathrm{M}$ urea. Fractions were collected, dialyzed against TBS, and assayed by sandwich ELISA with two different capture antibodies, TY monoclonal anti-NAP-1 $(\mathrm{O}-\mathrm{O})$ and $\mathrm{CC}$ monoclonal anti-

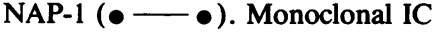
anti-NAP-1, which does not interact with native NAP-1-IgG (Table III, last row), functions as a capture antibody for urea-treated NAP-1-IgG. Molecular mass markers: $(A) \mathrm{IgG} ;(B)$ serum albumin; $(C)$ chymotrypsinogen; $(D)$ cytochrome $c$. Continuous tracing: $\mathrm{A}_{\mathbf{2 8 0}}$. 


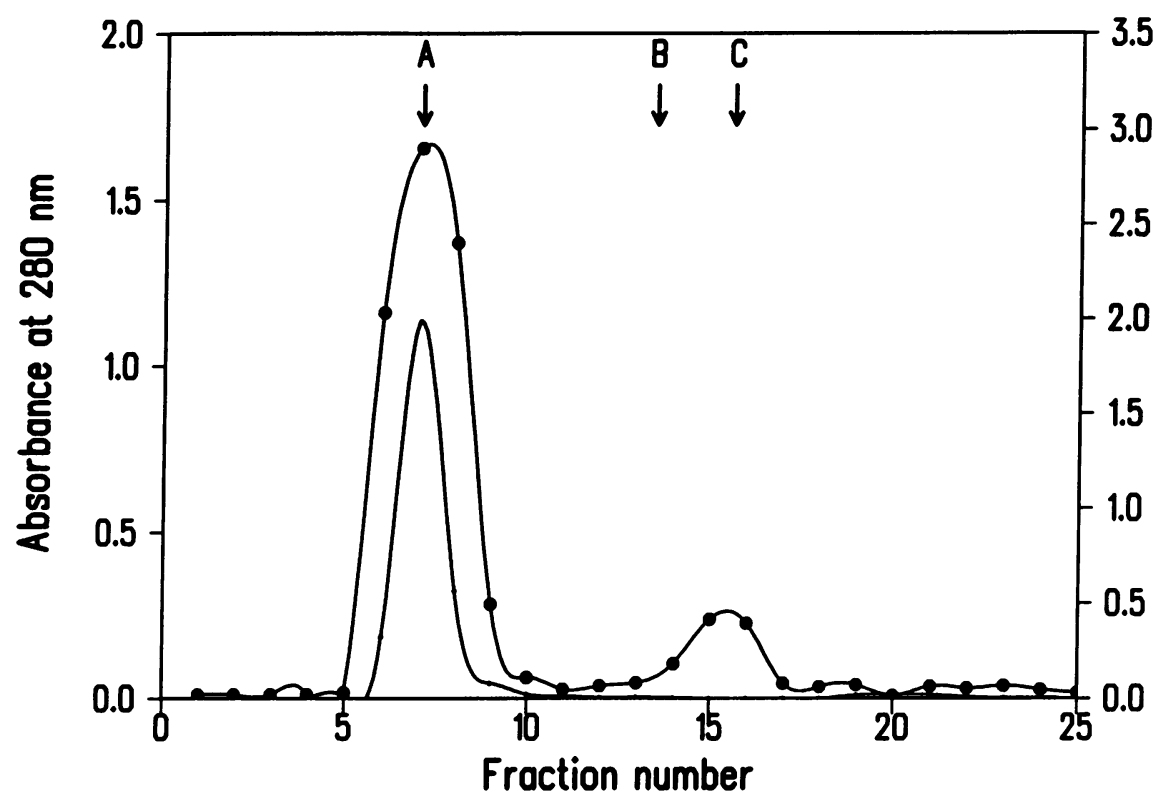

Figure 7. Gel filtration of NAP-1-IgG on Sephadex G-100 in $9 \mathrm{M}$ urea at $\mathrm{pH}$ 2.0. NAP-1-IgG was dialyzed against $0.1 \mathrm{M}$ glycine- $\mathrm{HCl}$ buffer, $\mathrm{pH} 2.0$. Urea was added to the sample at a final concentration of $9 \mathrm{M}$. Equilibration of the column and elution was performed in $0.1 \mathrm{M}$ glycine- $\mathrm{HCl}$ buffer with $9 \mathrm{M}$ urea at $\mathrm{pH}$ 2.0. Fractions were dialyzed against TBS and assayed for unfolded NAP-1-IgG and free NAP-1 in the sandwich ELISA with monoclonal 1C anti-NAP-1. Continuous tracing: $A_{280}$. Closed circles: sandwich ELISA. Molecular mass markers: $(A)$ human IgG; $(B)$ cytochrome $c$; $(C)$ expected position for free NAP-1, based on elution volume plot of molecular mass markers.
NAP-1-IgG had no effect on binding of ${ }^{125}$ I-NAP-1 to human neutrophils. This indicates that NAP-1-IgG does not bind to neutrophil NAP-1 receptors.

Human serum concentrations of NAP-1-IgG: differences between subjects, but constant values over time for individual subjects. Fig. 9 shows serum concentrations of NAP-1-IgG for 26 normal human subjects. There is a wide range of concentrations and no correlation with age or sex. The mean for the group is $58 \mathrm{ng}$ of complex NAP- $1 / \mathrm{ml}$ serum, with a SEM of 16 and a range from undetectable to $247 \mathrm{ng} / \mathrm{ml}$.

NAP-1-IgG was measured in paired sera obtained at a 1mo interval from 12 normal subjects. Serum was prepared as described in Methods and stored in aliquots at $-80^{\circ} \mathrm{C}$. Paired sera from each subject were assayed on the same day. For all 12 subjects there was no detectable alteration in the serum concentration of NAP-1-IgG over the 1-mo interval. This remarkable finding applied equally to the three subjects with undetectable NAP-1-IgG, to subjects with intermediate values, and to the person with $247 \mathrm{ng} / \mathrm{ml}$.

The undetectable levels of NAP-1-IgG in serum of 8 of the 26 subjects suggested the possibility of a NAP-1 isoform that did not react with the monoclonal capture antibody. Therefore we stimulated the PBMCs of two subjects, one with high, and the other with undetectable, serum NAP-1-IgG. The sandwich ELISA detected comparable amounts of NAP-1 in both culture fluids. This showed that the absence of detectable serum NAP-

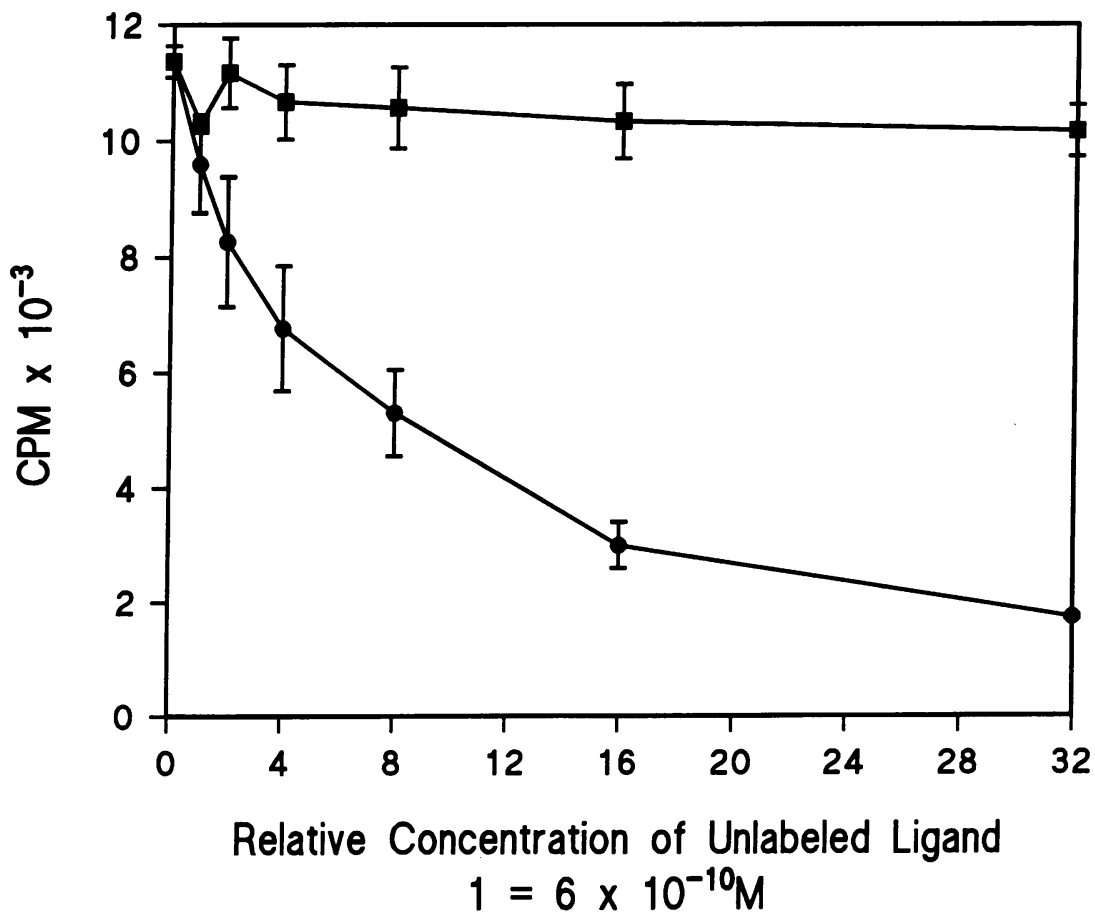

Figure 8. Inhibition of ${ }^{125} \mathrm{I}-\mathrm{NAP}-1$ binding to human neutrophils by NAP-1, but not by NAP-1IgG. Aliquots of $100 \mu$ l of neutrophil suspensions were equilibrated for $2 \mathrm{~h}$ at $0^{\circ} \mathrm{C}$ with $50 \mu \mathrm{l}$ of 1.2 $\times 10^{-8} \mathrm{M}^{125} \mathrm{I}-\mathrm{NAP}-1$ and $50 \mu \mathrm{l}$ of diluent or a series of increasing concentrations of NAP-1 or NAP-1-IgG. Cells were then centrifuged through oil and cell pellets were counted in a gamma counter. Data are means \pm SEM for experiments with neutrophils from three normal subjects. 


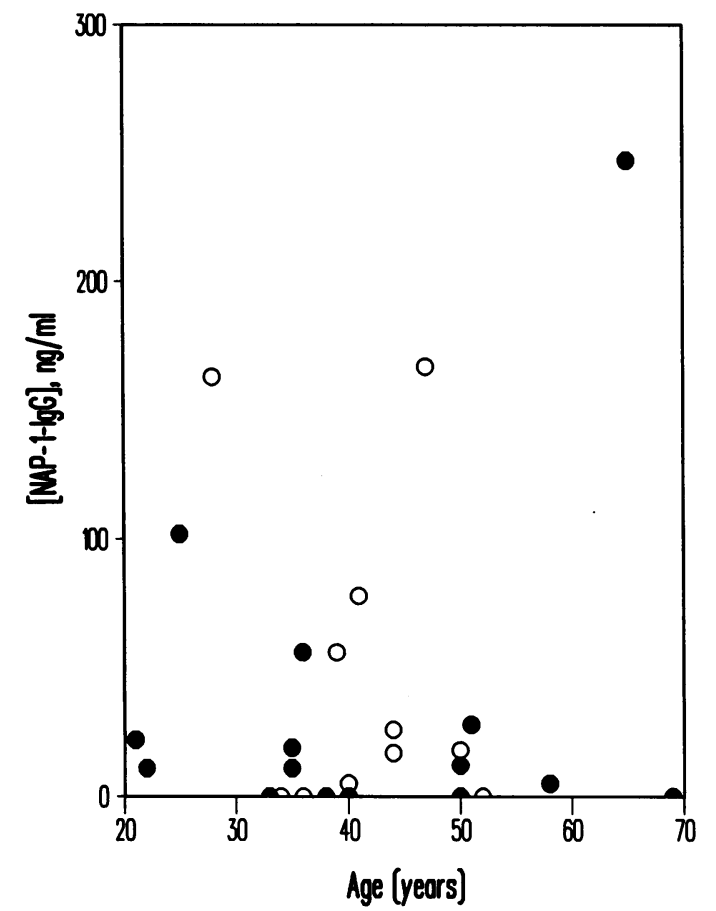

Figure 9. Concentration of NAP-1-IgG in sera of 26 normal human subjects. Closed circles: males. Open circles: females. Data were obtained by sandwich ELISA with TY monoclonal anti-NAP-1 as capture antibody. From the $A_{490}$ obtained for each serum in the NAP-1IgG assay, we subtracted the corresponding $A_{490}$ obtained for interaction between serum IgG and normal mouse IgG (see Methods). The concentration of NAP-1-IgG refers to weight of NAP-1, without the contribution of IgG. With TY monoclonal anti-NAP-1 and the ELISA amplification system, the NAP-1 detection limit was $\sim 1 \mathrm{ng} /$ ml.

1-IgG in one of the two individuals was not due to inability of the monoclonal capture antibody to interact with her NAP-1.

Survey of normal human sera for free NAP-1 and anti-NAP1. The presence of NAP-1-IgG in serum suggested that either free antigen or antibody might also be detectable. We surveyed the 26 sera with a sandwich ELISA for free NAP-1, using 1C monoclonal anti-NAP-1 as capture antibody since it does not bind NAP-1-IgG (Table III and Fig. $1 C$ ). Using this assay, which has a detection limit of $200 \mathrm{pg} / \mathrm{ml}$, we found no free NAP-1 in sera from the 26 normal subjects. In an attempt to concentrate possibly low concentrations of NAP-1 in human serum, we applied 5-ml aliquots of two human sera to monoclonal TY anti-NAP-1 Sepharose columns. In the glycine buffer eluate of a donor with undetectable serum NAP-1-IgG, we detected $700 \mathrm{pg}$ free NAP $-1 / \mathrm{ml}$ of eluate. This represents a serum concentration (assuming no losses) of $140 \mathrm{pg} / \mathrm{ml}$ since the column eluate was fivefold concentrated relative to the starting serum volume. No free NAP-1 was found in the glycine eluate of the other serum, which had a NAP-1-IgG concentration of $247 \mathrm{ng} / \mathrm{ml}$.

In contrast to the absence of free NAP-1, we detected free anti-NAP-1 antibody in 9 of the 26 sera by direct ELISA with recombinant NAP-1 adsorbed to the ELISA wells and IgG-depleted human albumin as the blocking agent ( see Methods and Table IV). We also detected free anti-NAP-1 antibody in highly purified commercially available human IgG (ChromoPure IgG). One of the nine sera was also tested for capacity to immunoprecipitate metabolically labeled NAP-1; the resulting radioactive band was comparable in location to that obtained with rabbit anti-NAP-1 (data not shown).

The light chain isotype and IgG subclass of free anti-NAP-1 antibody were determined in Protein-G-purified IgG samples from eight donors and also in commercial human IgG (see Methods). Both kappa and lambda light chains were detected in all samples, indicating that anti-NAP-1 autoantibody is polyclonal (data not shown). $\mathrm{A}_{405}$ values obtained with IgG subclass-specific antibodies are shown in Fig. 10. IgG2 and IgG3 were the predominant subclasses of anti-NAP-1 autoantibodies in the IgG of all donors as well as in commercial IgG. The low level of IgG1 in the anti-NAP-1 fraction of human IgG is remarkable, in view of the fact that it comprises $\sim 65 \%$ of the total IgG in normal human serum.

\section{Discussion}

Evidence relevant to our hypothesis that NAP-1 ELISA reactivity in human serum is due to NAP-1-IgG is as follows: $(a)$ NAP-1 sandwich ELISA values for serum were the same, with or without the addition of rabbit IgG anti-NAP-1 detection antibody (Table I). This led to the schema outlined in Fig. $1 B$.

Table IV. Detection by ELISA of Anti-NAP-1 and NAP-1-IgG in Normal Human Sera

\begin{tabular}{lccc}
\hline Donor & Age & Anti-NAP-1* & NAP-1-IgG \\
\hline & & $n g / m l$ & $n g / m l$ \\
KM & 44 & 9 & 8 \\
KF & 69 & 42 & 0 \\
MF & 41 & 24 & 78 \\
OH & 50 & 15 & 0 \\
EL & 65 & 99 & 247 \\
MB & 47 & 24 & 167 \\
DL & 25 & 63 & 102 \\
KZ & 36 & 45 & 56 \\
JT & 40 & 54 & 0 \\
\hline
\end{tabular}

* ELISA wells, except for controls, were coated with NAP-1 and blocked with HSA. A 1:3 dilution of each serum was added to triplicate wells coated with NAP-1 or HSA. Detection antibody was alkaline phosphatase-labeled goat anti-human IgG. For each serum, the difference between the $A_{405}$ for NAP-1-coated wells and HSA control wells was calculated. Estimates of serum anti-NAP-1 concentration were determined graphically by reference to a concentration-response curve generated by adding dilutions of IgG monoclonal anti-NAP-1 to ELISA wells coated with NAP-1. The column shows values for the 9 sera of 26 tested that were significantly different from background by $t$ test (18), $P \leq 0.025$. The mean \pm SEM for the group is $42 \pm 9 \mathrm{ng} /$ $\mathrm{ml}$. The value is an estimate, since it could be affected by differences in affinity of human or mouse antibody for NAP-1. ${ }^{\ddagger}$ The column shows concentration of NAP-1-IgG in the sera of those subjects with detectable free anti-NAP-1 autoantibody, determined on serial dilutions of serum by sandwich ELISA with TY monoclonal anti-NAP-1 as capture antibody and alkaline phosphate-labeled goat anti-human IgG as detecting antibody. Concentration was calculated with reference to a standard NAP-1 ELISA curve after the subtraction of corresponding $A_{490}$ values because of the interaction of human serum IgG and normal mouse IgG. The concentration of NAP-1-IgG refers to the IgG-bound NAP-1, excluding the weight of IgG. NAP-1 detection limit of the ELISA was $\sim 1 \mathrm{ng} / \mathrm{ml}$. 


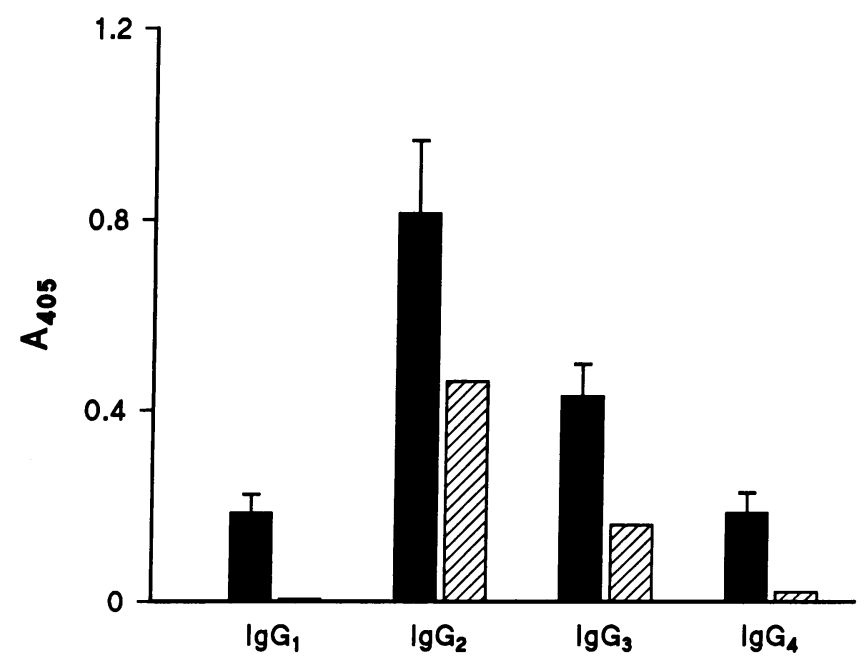

Figure 10. IgG subclass determination of human anti-NAP-1 autoantibody. ELISA wells (except for controls) were coated with NAP-1 and blocked with HSA. Protein-G purified donor IgG from eight individuals with detectable free anti-NAP-1 antibody or commercial normal human IgG was added to assay wells at a concentration of $1 \mathrm{mg} / \mathrm{ml}$, followed by mAbs to the four IgG subclasses (see Methods). Alkaline phosphatase-conjugated goat anti-mouse IgG, which does not cross react with human IgG, was used as a second antibody. Background values due to HSA-IgG interactions were subtracted from the absorbance in the NAP-1 containing wells. Solid bars: mean $A_{405}$ values due to free anti-NAP-1 IgG subclasses in eight donors, error bars representing SEM. Cross-hatched bars: $\mathrm{A}_{405}$ values for anti-NAP-1 subclasses in commercial normal human IgG. (SEMs for triplicates were $<5 \%$ ).

(b) Reactivity was not due to interaction of human IgG with mouse IgG adsorbed to the plastic. (c) ELISA-reactive material was bound to and eluted from a monoclonal IgG anti-NAP-1 Sepharose column, but not Sepharose or control IgG Sepharose columns. (d) When immunoaffinity purified material was applied to an HPLC gel filtration column, ELISA reactivity eluted in a single peak, corresponding to the IgG marker. (e) Free anti-NAP-1 antibody was found in 9 of 26 sera assayed, indicating the potential for immune complex formation. $(f)$ Although we were unable to dissociate NAP-1 from NAP-1IgG in 8 or $9 \mathrm{M}$ urea at neutral or alkaline $\mathrm{pH}$, this treatment made the complex capable of binding to $1 \mathrm{C}$ monoclonal antiNAP-1 (which does not bind the native complex, Fig. 1C). This suggests that partial unfolding occurred, exposing a NAP1 epitope that is buried in the native complex. Furthermore, 9 $\mathrm{M}$ urea at $\mathrm{pH} 2.0$ caused $\sim 15 \%$ of the total NAP- 1 in the complex to dissociate, and it eluted from a gel filtration column in a location corresponding to free NAP-1.

Using a sandwich ELISA with a detection limit of $200 \mathrm{pg} /$ $\mathrm{ml}$, we found no free NAP-1 in our group of 26 normal human sera. It was detected in immunoaffinity column eluates from one of two sera that were concentrated fivefold relative to serum concentration. The serum of this individual contained neither detectable NAP-1-IgG nor detectable free anti-NAP-1 antibody. Our results for free NAP-1 in serum are consistent with data in the literature. For example, Martich et al. (11) detected NAP-1 concentrations of $26-46 \mathrm{pg} / \mathrm{ml}$ in 4 of 25 normal subjects, levels that are below the detection limit of our assay. Control human sera (number not specified) for experiments reported by Davenport et al. (19) had NAP-1 concentra- tions of $\sim 100 \mathrm{pg} / \mathrm{ml}$. The data of Martich et al. (11) are for free NAP-1, since the capture antibody in the sandwich ELISA was monoclonal 1C anti-NAP-1, which does not react with NAP-1-IgG. Thus, the concentration of free NAP-1 in normal human serum is undetectable or in the low picogram range. This is in contrast to NAP-1-IgG, which is in the nanogram range (mean of $58 \mathrm{ng} / \mathrm{ml}$, excluding the IgG weight).

Investigation of the different specificities and cross-reactivities of monoclonal anti-NAP-1 antibodies have led us to postulate a surprisingly large number of different epitopes for this relatively small protein (Fig. 1, legend). In this context, what is the meaning of undetectable NAP-1-IgG in eight of the surveyed sera? Could those sera have a NAP-1 immune complex, the IgG of which blocks the epitopes required for interaction with capture antibody? To evaluate this possibility, we assayed the negative sera in two additional ELISAs for NAP-1-IgG, using monoclonals 14E4 and 52E8 as capture antibodies, which bind to different NAP-1 epitopes. The negative sera also had undetectable NAP-1-IgG in these assays (data not shown), which makes the blocked epitope hypothesis unlikely. It is probable that the eight sera with undetectable NAP-1-IgG contain the complex at a concentration that is at the lower end of a broad distribution curve for normal humans.

The gel filtration data in Fig. 5 show that the bulk of NAP1-IgG, as determined by sandwich ELISA, eluted with the IgG marker. Thus, the immune complex comprises one IgG and one or at most two NAP-1 molecules per divalent IgG. The small shoulder at the beginning of the NAP-1-IgG ELISA peak is probably due to experimentally induced aggregation. However, in view of the evidence for several epitopes on the NAP-1 molecule, the shoulder could be a complex with two IgGs. Ishizaka et al. (20) showed that two IgGs in an immune complex were the minimum number required for eliciting skin reactivity or complement activation. Since the bulk of the NAP-1IgG immune complex comprises one IgG, it should not be pathogenic, a view supported by its presence in healthy human subjects.

The presence of NAP-1-IgG in normal human serum suggests the following hypothesis. Homeostatic responses in normal individuals include tissue cell secretion of NAP-1, which subsequently diffuses into the circulating blood. Since binding to blood neutrophils would inhibit the neutrophil response to a chemotactic gradient, prevention of binding by a NAP-1 trapping mechanism might exist, antibody, $\alpha 2$-macroglobulin, or other cells with NAP-1 receptors being possible examples. This role is fulfilled by NAP-1-IgG, which does not compete with ${ }^{125}$ I-NAP-1 for binding to neutrophil NAP-1 receptors (Fig. 8). The concentration of NAP-1-IgG in a group of normal human sera is in the nanogram range $(<1-247 \mathrm{ng} / \mathrm{ml}$, Fig. 9). The concentration of free NAP- 1 in serum of normal humans is in the picogram range (below a detection limit of $20-46 \mathrm{pg} / \mathrm{ml}$ (11)]. The concentration of serum anti-NAP-1 is $\sim 10-100$ $\mathrm{ng} / \mathrm{ml}$ ( Table IV). If we assume that the low concentration of free serum NAP-1 reflects equilibrium between antigen, antibody, and the complex, the $K_{d}$ of anti-NAP-1 must be $<\sim 10^{-11} \mathrm{M}$. Thus, under normal conditions, this high affinity antibody is capable of limiting free NAP-1 concentration in the serum to a reported level (the order of $10^{-12} \mathrm{M}$ ) that is considerably below the optimal neutrophil stimulatory concentration of $10^{-8} \mathrm{M}$. In response to intravenous LPS, a powerful stimulus for NAP-1 secretion, the serum concentration of free NAP-1 rose to a peak of $500-900 \mathrm{pg} / \mathrm{ml}\left(\sim 10^{-10} \mathrm{M}\right)$ 
within $3 \mathrm{~h}$ (11). It would be of interest to know if serum antiNAP-1 in these subjects was saturated by a flood of secreted NAP-1, resulting in elevated NAP-1-IgG as well as detectable free NAP-1.

Cells in the circulating blood other than neutrophils are capable of binding NAP-1. We reported that human monocytes bind NAP-1, despite lack of a chemotactic response (16). In an interesting publication by Darbonne et al. (21), it was shown that human erythrocytes were capable of binding ${ }^{125} \mathrm{I}$ NAP-1 with a $K_{d}$ of $5 \times 10^{-9} \mathrm{M}$. The authors did not report attempts to detect a preexisting NAP-1-erythrocyte complex in blood. Such a complex appears to be unlikely, given a $K_{\mathrm{d}}$ of 5 $\times 10^{-9} \mathrm{M}$ and a serum free NAP-1 concentration on the order of $10^{-12} \mathrm{M}$. Thus, the in vivo significance of the NAP-1-binding capacity of erythrocytes remains to be determined.

If serum NAP-1-IgG reflects a trapping mechanism to maintain free chemoattractant at low levels, the same might apply to other chemoattractants. Therefore, we looked for an IgG complex with monocyte chemoattractant protein-1 (MCP-1), a recently described attractant with $24 \%$ sequence similarity to NAP-1 $(22,23)$. MCP-1-IgG was found in all 26 sera from the NAP-1-IgG study group. In relation to the possibility of an IgG trap for small protein attractants in general, it will be pertinent to develop assays for a serum C5a-IgG complex.

It is of interest that we found free anti-NAP-1 antibody in 9 of 26 sera by ELISA. Antibody to IL- 1 and TNF has been found in the serum of normal subjects (24). In a recent review, Avrameas (25) lists antibodies to other proteins found in normal serum, including interferons and TNF. Does production of antibody to these proteins reflect abrogation of tolerance or is tolerance never developed?

IgG-anti-NAP-1 comprised both kappa and lambda light chain isotypes in all nine normal subjects with detectable free anti-NAP-1, which shows that these auto-antibodies are polyclonal. The relatively high ELISA $\mathrm{A}_{405}$ values for IgG2 and IgG3 anti-NAP-1 subclasses of eight normal subjects were similar to the $\mathrm{A}_{\mathbf{4 0 5}}$ distribution pattern found for anti-NAP-1 subclasses in commercial IgG (Fig. 10). This suggests that the observed distribution for the eight normal subjects reflects that of the general population. Although we do not know how closely the $\mathrm{A}_{405}$ values of Fig. 10 reflect subclass concentrations, the data suggest that the relative concentration of $\operatorname{IgG} 1$ anti-NAP- 1 is considerably less than the $65 \%$ IgG 1 reported for total serum IgG. The significance of this apparent predominance of IgG2 and IgG3 among anti-NAP-1 antibodies is not known. It will be of interest to determine the subclass of other nonpathogenic autoantibodies that have a possible role in homeostasis. Subclass heterogeneity of the autoantibody may also be associated with differences in affinity, which could account for incomplete dissociation of the NAP-1-IgG complex at $\mathrm{pH}$ 2.0 in $9 \mathrm{M}$ urea.

Although the concentration of NAP-1-IgG in normal human serum covered a wide range, the concentration in any individual measured at a 1-mo interval was remarkably constant. This stability may relate to mechanisms for removal of the complex. As noted above, NAP-1-IgG will not be ingested via Fc receptors of phagocytic cells, since complexes with a single IgG fail to activate pathways of Fc transduction. The relatively stable serum level of NAP-1-IgG in individual sera can be accounted for if we assume that NAP-1-IgG is eliminated by a first-order reaction with a $23-d$ half-life, similar to that of free $\operatorname{IgG}(26)$. In the steady state, production (and degradation) of the complex would be $\sim 3 \%$ of the total per day. Therefore, a threefold increase in the rate of NAP-1 complex formation for $1 \mathrm{~d}$ would make a change of only $9 \%$ in the total concentration of NAP-1-IgG. In other words, a relatively long half-life minimizes changes in NAP-1-IgG concentration secondary to fluctuations in NAP-1 production.

Since we have developed assays that can quantify NAP-1 and NAP-1-IgG independently of one another, it will now be practical to look for alterations in disease. In fact, the studies described in this paper were stimulated by the finding of NAP1 ELISA reactivity in synovial fluids of patients with arthritis. We then asked whether the presumed NAP-1 was generated by synovial tissue or reflected serum protein concentrations characteristic of an exudate. This led to detection of NAP-1 ELISA reactivity in normal serum and to the studies described in this paper. Using assays for free NAP-1 and the complex, we found NAP-1-IgG concentrations of 4-42 ng/ ml, but no free NAP-1 (detection limit $1 \mathrm{ng} / \mathrm{ml}$ ), in 14 of 16 inflammatory joint fluids (unpublished data). Based on a radioimmunoassay with a rabbit anti-NAP-1 antibody, Brennan et al. (6) reported NAP-1 concentrations in the range of $1-9 \mathrm{ng} / \mathrm{ml}$ in joint fluids from patients with rheumatoid and non-rheumatoid arthritis. Did that study detect free NAP-1, NAP-1-IgG, or both? If the epitopes with which their rabbit anti-NAP-1 reacts are blocked by the IgG of NAP-1-IgG, the radioimmunoassay might have detected only free NAP-1. Evaluation of the specificity of the radioimmunoassay could now be made by testing pure NAP-1 and serum-derived NAP-1-IgG.

Measurement of serum NAP-1 or NAP-1-IgG might be diagnostically useful in certain clinical conditions. An example is pulmonary fibrosis, the management of which depends in part on knowing when intermittent episodes of clinically silent pulmonary inflammation occur. Diagnostic bronchoalveolar lavage has been advocated. A less invasive approach would be preferable. If serum NAP-1 or NAP-1-IgG increased during inflammatory episodes, this finding could be used as an indication for therapy. Detection of serum neutrophil chemotactic factor in asthma is an example of a locally elaborated cytokine recoverable in the circulation (27); and a rising serum NAP-1 has been found in experimentally induced endotoxemia or sepsis (28).

\section{Acknowledgments}

We thank Dr. John Rankin for his critical review of the manuscript, Robert Poindexter for his gift of IgG isotype antisera, and Alison Skeel for iodination of NAP-1 as well as expert technical help.

I. Sylvester was supported in part by a Cooperative Research and Development Agreement with Baxter Health Care Corp. (Roundlake, IL).

Note added in proof. Monoclonal antibodies that bind both NAP-1 and NAP-1-IgG are suitable for detection of NAP-1 in sera containing NAP-1-IgG if phosphatase-conjugated anti-rabbit IgG that does not cross-react with human IgG (Catalogue No. 711-055-132; Jackson Laboratories, West Grove, PA) is used in the last step of the ELISA.

\section{References}

1. Leonard, E. J. 1990. NAP-1 (IL-8). Immunol. Today. 11:223-224.

2. Leonard, E. J., and T. Yoshimura. 1990. Neutrophil attractant/activation protein-1 (NAP-1 [Interleukin-8]). Am. J. Respir. Cell Mol. Biol. 2:479-486.

3. Yoshimura, T., K. Matsushima, S. Tanaka, E. A. Robinson, E. Appella, 
J. J. Oppenheim, and E. J. Leonard. 1987. Purification of a human monocyte-derived neutrophil chemotactic factor that has peptide sequence similarity to other host defense cytokines. Proc. Natl. Acad. Sci. USA. 84:9233-9237.

4. Schröder, J.-M., and E. Christophers. 1986. Identification of a C5a $\mathrm{ades}_{\text {arg }}$ and an anionic neutrophil activating peptide (ANAP) in psoriatic scales. $J$. Invest. Dermatol. 87:53-58.

5. Beaubien, B. C., P. D. Collins, P. J. Jose, N. F. Totty, J. Hsuan, M. D. Waterfield, and T. J. Williams. 1990. A novel neutrophil chemoattractant generated during an inflammatory reaction in the rabbit peritoneal cavity in vivo. Biochem. J. 271:797-804.

6. Brennan, F. M., C. O. C. Zachariae, D. Chantry, C. G. Larsen, M. Turner, R. N. Maini, K. Matsushima, and M. Feldmann. 1990. Detection of interleukin 8 biological activity in synovial fluids from patients with rheumatoid arthritis and production of interleukin $8 \mathrm{mRNA}$ by isolated synovial cells. Eur. J. Immunol. 20:2141-2144.

7. Fick, R. B., T. J. Standiford, S. L. Kunkel, and R. M. Strieter. 1991. Interleukin-8 (IL-8) and neutrophil accumulation in the inflammatory airways disease of cystic fibrosis (CF). Clin. Res. 39:292A.

8. Yoshimura, T., E. A. Robinson, E. Appella, K. Matsushima, S. D. Sho walter, A. Skeel, and E. L. Leonard. 1989. Three forms of monocyte-derived neutrophil chemotactic factor (MDNCF) distinguished by different lengths of the amino-terminal sequence. Mol. Immunol. 26:87-93.

9. Sylvester, I., J. A. Rankin, T. Yoshimura, S. Tanaka, and E. J. Leonard 1990. Secretion of neutrophil attractant/activation protein by lipopolysaccharide-stimulated lung macrophages determined by both enzyme-linked immunosorbent assay and N-terminal sequence analysis. Am. Rev. Respir. Dis. 141:683688.

10. Sticherling, M., J.-M. Schröder, and E. Christophers. 1989. Production and characterization of monoclonal antibodies against the novel neutrophil activating peptide NAP-1/IL-8. J. Immunol. 143:628-1634.

11. Martich, G. D., R. L. Danner, M. Ceska, and A. F. Suffredini. 1991. Detection of interleukin 8 and tumor necrosis factor in normal humans after intravenous endotoxin. The effect of antiinflammatory agents. J. Exp. Med. 173:1021-1024.

12. Ceska, M., F. Effenberger, P. Peichl, and E. Pursch. 1989. Purification and characterization of monoclonal and polyclonal antibodies to neutrophil activation peptide (NAP-1). The development of highly sensitive ELISA methods for the determination of NAP-1 and anti-NAP-1 antibodies. Cytokines. 1:136a. (Abstr.)

13. Boscato, L. M., and M. C. Stuart. 1988. Heterophilic antibodies: a problem for all immunoassays. Clin. Chem. 34:27-33.

14. Leonard, E. J., and A. Skeel. 1980. Functional differences between resi- dent and exudate peritoneal mouse macrophages: specific serum protein requirements for responsiveness to chemotaxins. J. Reticuloendothel. Soc. 28:437-447

15. Castor, C. W. 1988. Regulation of connective tissue metabolism. In Arthritis and Allied Conditions. D. J. McMarty, editor. 11 th ed. Lea \& Febiger, Philadelphia. 242-263.

16. Leonard, E. J., A. Skeel, T. Yoshimura, K. Noer, S. Kutvirt, and D. Van Epps. 1990. Leukocyte specificity and binding of human neutrophil attractant/ activation protein-1. J. Immunol. 144:1323-1330.

17. Samanta, A. K., J. J. Oppenheim, and K. Matsushima. 1989. Identification and characterization of specific receptors for monocyte-derived neutrophil chemotactic factor (MDNCF) on human neutrophils. J. Exp. Med. 169:11851189.

18. Snedecor, G. W., and W. G. Cochran. 1967. Statistical Methods. The Iowa State University Press, Ames, IA. 102.

19. Davenport, R. D., R. M. Strieter, T. J. Standiford, and S. L. Kunkel. 1990 Interleukin-8 production in red blood cell incompatibility. Blood. 76:2439-2442.

20. Ishizaka, K., T. Ishizaka, and J. Banovitz. 1964. Biologic activity of soluble antigen-antibody complexes. IX. Soluble complexes of rabbit antibody with univalent and divalent haptens. J. Immunol. 93:1001-1007.

21. Darbonne, W. C., G. C. Rice, M. A. Mohler, T. Apple, C. A. Hébert, A. J. Valente, and J. B. Baker. 1991. Red blood cells are a sink for interleukin 8, a leukocyte chemotaxin. J. Clin. Invest. 88:1362-1369.

22. Yoshimura, T., N. Yuhki, S. K. Moore, E. Appella, M. I. Lerman, and E. J. Leonard. 1989. Human monocyte chemoattractant protein-1 (MCP-1): full-length cDNA cloning, expression in mitogen-stimulated blood mononuclear leukocytes, and sequence similarity to mouse competence gene JE. FEBS ( Fed. Eur. Biochem. Soc.) Lett. 244:487-493.

23. Leonard, E. J., and T. Yoshimura. 1990. Human monocyte chemoattractant protein-1 (MCP-1). Immunol. Today. 11:97-101.

24. Bendtzen, K., M. Svenson, A. Foomsgaard, L. K. Poulsen, and M. Hansen. 1989. Auto-antibodies to IL- $\alpha$ and TNF $\alpha$ in normal individuals and in infectious and immunoinflammatory disorders. Cytokine. 1:89a. (Abstr.)

25. Avrameas, S. 1991. Natural autoantibodies: from 'horror autotoxicus' to 'gnothi seauton.' Immunol. Today. 12:154-166.

26. Paul, W. E., editor. 1989. Fundamental Immunology. 2nd ed. Raven Press, New York. p. 226

27. Buchanan, D. R., O. Cromwell, and A. B. Kay. 1987. Neutrophil chemotactic activity in acute severe asthma (status asthmaticus). Am. Rev. Respir. Dis. 1136:1397-1402.

28. van Zee, K. J., L. E. DeForge, E. Fischer, M. A. Marano, J. S. Kenney, D. G. Remick, S. F. Lowry, and L. L. Moldawer. 1991. IL-8 in septic shock, endotoxemia, and after IL-1 administration. J. Immunol. 146:3478-3482. 